\title{
PENYULUHAN ZAKAT PADI BAGI MASYARAKAT BENDOSARI
}

\author{
Fauzul Hanif Noor Athief ${ }^{1}$, Dzaky Adam Thamrin ${ }^{2}$ \\ 1,2Program Studi Hukum Ekonomi Syariah, Universitas Muhammadiyah Surakarta \\ Email: fauzul.hanif@ums.ac.id, dzakythamrin94@gmail.com
}

\begin{abstract}
The Bendosari village which is located at Sukoharjo is an area with a far distance to the center of the city. It is difficult to rich this area unless someone do it purposely. Under this cirumstances, the access for preacher from outside the villagers in order to contribute in developing Islamic teaching among them is quite difficult. While that is the hindrance for the preacher to reach the area, the villagers themselves mostly are occupied as farmer who will deal with the zakat of plantation in their daliy life. The lack of preacher at the area and the day to day dealing with zakat matters create a necessity to make community engagement with the citizen. Here the author tries to investigate the exact necessity of the villagers and then deals directly with their problem by conducting a seminar to them. The result shows that villagers understanding on zakat matter, especially for the paddy increase significantly after the seminar.
\end{abstract}

Keywords: zakat, paddy, farmer

\begin{abstract}
Abstrak. Desa Bendosari yang berlokasi di Sukoharjo adalah sebuah area yang terletak cukup jauh dari pusat kota. Cukup sulit untuk mencapai area ini kecuali memang orang tersebut berniat untuk mengunjunginya. Dengan kondisi seperti ini, akses untuk para penceramah dari luar desa untuk dapat memberi sumbangsih terhadap pengetahuan keagamaan Islam menjadi terkendala. Pada saat penceramah mempunyai kendala untuk mengakses area tersebut, para penduduk desa sendiri kebanyak bermatapencaharian sebagai petani yang kehidupannya selalu bersinggungan dengan zakat tanaman pada kegiatan harian mereka. Kurangnya jumlah penceramah pada desa tersebut serta kegiatan harian yang bekenaan dengan zakat tanaman menjadikan kegiatan pengabdian masyarakat dibutuhkan. Pada artikel ini penulis mencoba untuk menginvestigasi keperluan dari para penduduk desa untuk kemudian diberikan solusinya kepada mereka dengan cara memberikan seminar. Hasil menunjukkan bahwa para pemahaman penduduk desa terkait zakat tanaman, khususnya zakat padi meningkat secara signifikan setelah diadakannya seminar.
\end{abstract}

Kata kunci: zakat, padi, petani.

\section{PENDAHULUAN}

Indonesia adalah Negara dengan penduduk Muslim terbanyak di dunia.Dari lebih dari 250 juta rakyaktnya, sekitar 200 juta lebih memeluk agama Islam. Hal ini tentu menjadikan Indonesia sebagai Negara dengan potensi terbesar berbasis populasi muslim. Potensi tersebut termasuk dalam hal perbankan Islam, halal lifestyle, halal tourism, serta tentunya potensi dalam hal ZISWAF (Zakat, Infak, Sedekah dan Wakaf).Dalam ranah zakat, telah banyak peneliti maupun praktisi di bidang ini yang menyatakan bahwa realisasi zakat masih jauh dari potensi yang diharapkan (Mubarok dan Fanani, 2014; Canggih et al., 2017).

Potensi zakat Indonesia sendiri mencapai Rp. 6.132 Triliun menurut PIRAC (Kurniawati, 2004). Adapun pada tahun 2014, realisasi penerimaan zakat di Indonesia hanya sebesar Rp.
3,2 triliun (Sitorus, 2015). Jauhnya praktek zakat dari potensi yang diharapkan tidak terlepas dari berbagai faktor, termasuk ketidapahaman pihakpihak wajib zakat yang membuat mereka tidak menunaikan pembayaran zakat.Ketidakpahaman sendiri bisa disebabkan berbagai hal seperti kurangnya edukasi dan informasi yang didapatkan maupun tersedia terkait praktek zakat.Maka dari itu, sosialisasi yang diadakan dengan tujuan meningkatkan pemahaman pihak wajib zakat adalah salah satu solusi yang bisa ditawarkan untuk membantu masyarakat lebih jauh mengenal zakat (Mukhlis \& Beik, 2013). Pada akhirnya, masyarakat akan menunaikan zakatnya dan pada saat yang sama jumlah zakat terkumpul dalam kumulatif nasional bisa meningkat.

Badan Amil Zakat Nasional (BAZNAS) kita sendiri sebenarnya telah mencoba melakukan banyak sosialsi terkait zakat.Hanya saja, luas 
Indonesia yang mencapai hampir 2 juta kilometer persegi tentu masih menyisakan wilayah-wilayah kecil yang belum bisa terjamah oleh BAZNAS dikarenakan keterbatasan jumlah tenaga dan waktu mereka.

Jika BAZNAS sebagai otoritas yang khusus membidangi zakat tidak mampu, maka tonggak selanjutnya adalah para penceramah penyuluh agama atau dai. Jumlah penyuluh agama memang cukup banyak, bahkan di beberapa tempat yang terpencil sekalipun mempunyai penyuluh agama mereka sendiri.Tetapi sebagaimana yang kita dapati, kebanyakan dari penceramah baru membahas seputar kajian akhlak.Hanya sedikit dari program ceramah ataupun pengajian yang spesifik membahas topik zakat. Hal ini tentu berakar dari sumber daya manusia para dai yang tidak semuanya menekuni bidang zakat sehingga membuat keterbatasan dalam materi ceramah. Kajian seputar zakat biasanya hanya kita temui pada model-model seminar, workshop atau pelatihan berkelanjutan sehingga membuat manfaat sosialisasi pengetahuan seputar zakat tersebut kurang inklusif.

Kurang tepatnya materi ceramah, keterbatasan kemampuan penceramah, serja kajian yang kurang inklusif menyisakan celah bagi para pegiat zakat lainnya untuk terus mengadakan sosialisasi.Belum lagi dengan kenyataan lapangan bahwa zakat pertanian itu wajib sedangkan justru kebanyakan dari petani tinggal di pelosok dengan jumlah penceramah yang minim serta ketiadaan akses untuk mengikuti seminar khusus terkait zakat. Baik dari faktor pemberi penyuluhan yaitu dai, maupun masyarakat wajib zakat pertanian yaitu petani di pelosok desa mengisyaratkan urgensi dan sosialisasi terhadap kelompok masyarakat yang memang membutuhkan edukasi. Hal ini karena edukasi juga membantu membentuk niat penyalur zakat yang merupakan salah satu variabel penting dalam pembayaran zakat (Huda et al., 2012). Bahkan menurut Sedjati dkk (2018), pengetahuan sama pentingnya dengan level pendapatan dalam hal faktor pendorong pembayaran zakat.

Faktor-faktor yang disebutkan di atas juga terdapat pada masyarakat Desa Bendosari Rt.2/Rw.1 Sukoharjo. Sehubungan dengan hal tersebut, sesuai dengan komitmen Muhammadiyah untuk memberi manfaat sebesarbesarnya kepada umat, maka perlu diadakan kegiatan pengabdian kepada kelompok masyarakat ini. Kegiatan pengabdian ini tentunya diharapkan member pengetahuan yang cukup signifikan agar selanjutnya pihak-pihak wajib zakat dari masyarakat ini maupun sanak keluarga mereka bisa mempraktekkan zakat pertanian dengan spesifik zakat padi sebagaimana dicanangkan oleh Islam.

Zakat adalah hal yang tidak secara detail dijelaskan di dalam Alquran. Praktek teknis zakat baru bisa didapati pada Hadis maupun penjelasan para ulama pada bab fikih. Hal ini membuat pemahaman zakat memerlukan pembelajaran khusus, terlebih bagi masyarakat awam.Dengan profil masyarakat Desa Bendosari yang mayoritas berpforesi sebagai petani, tentu menjadi suatu kendala bagi mereka untuk memahami permasalahan zakat dari sumber utama secara langsung.Jika dipaksakan, yang ditakutkan terjadi justru misinterpretasi atas teori-teori zakat.Dikarenakan kebanyakan masyarakat mempunyai lapangan pencaharian sebagai petani, maka yang perlu dipahami lebih dalam adalah kajian zakat spesifik di bidang pertanian. Maka dari itu, sangat perlu diadakan kegiatan pengabdian pada pokok permasalahan ini dengan tema yang akan disajikan adalah "Penyuluhan Teori Zakat Padi di Masjid Al-Ikhlas Desa Bendosari Rt.2/Rw.01”.

Adapun faktor lain yang membuat program penyuluhan ini sangat penting adalah sebagai berikut:

1. Pemahaman masyarakat desa Bendosariyang secara umum masih rendah atas teori zakat, khususnya dalam zakat pertanian spesifik padi berdasarkan apa yang telah diturunkan pada Alquran dan dijabarkan pada hadishadis Rasul SAW serta dieksplorasi lebih jauh oleh para ulama.

2. Beberapa jamaah tergolong sangat awam dikarenakan keterbatasan pemahaman pada tema zakat secara umum.

3. Ketidakpahaman masyarakat akan zakat pertanian spesifik padi membuat praktek zakat masih simpang siur termasuk di antara jamaah. Hal ini mengakibatkan 
ketidaksempurnaan penunaian zakat oleh mereka.

4. Segolongan masyarakat memahami teori zakat dengan kurang tepat sehingga justru praktek zakat yang dilaksanakan masyarakat tidak sesuai, baik itu melebih-lebihkan atau mengurangi porsi zakat yang harus dan wajib ditunaikan.

\section{METODE PELAKSANAAN KEGIATAN}

Adapun tahapan pelaksanaan kegiatan pengabdian masyarakat ini adalah sebagai berikut. Pertama adalah musyawarah dengan perangkat desa serta pengurus masjid Al-Ikhlas Bendosari untuk mendapatkan keterangan lengkap terkait kondisi warga Bendosari. Selanjutnya hasil musyawarah dijadikan acuan tentang materi yang perlu disampaikan kepada warga Bendosari agar materi yang disampaikan sesuai dengan kebutuhan dan dapat dipahami dengan mudah. Hasilnya diputuskan untuk melakukan kegiatan penyuluhan.

Kegiatan penyuluhan ini disusun untuk dapat diadakan dalam satu kali pertemuan.Hal ini dikarenakan lokasi yang memang cukup jauh untuk dijangkau.Dalam menghadapi problem jarak tersebut, maka penyuluhan direncanakan untuk berlangsung sekitar 2 jam.Adapun materi disusun secara komprehensif dan singkat menggunakan bahasa yang sangat mudah dimengerti oleh orang awam serta daerah terpencil. Penyampaian materi dilakukan dengan orasi satu arah(ceramah) yang kemudian dilanjutkan dengan dialog interaktif untuk memberi kesempatan kepada para jamaah untuk memperdalam kajian materi. Pengadaan dialog interaktif ini juga ditujukan untuk para jamaah agar menyampaikan permasalahan nyata yang memang sedang dihadapi masyarakat terkait zakat pertanian agar mendapat solusi.

Materi yang direncanakan untuk disampaikan pada pengabdian masyarakat ini disadur dari buku-buku serta referensi pokok terkait tema hadis pertanian dengan spesifik padi. Di antara buku-buku tersebut adalah:

1. Al-Fiqh Al-Islami wa Adillatuhu.

Buku ini adalah masterpiece karangan Wahbah Zuhaili yang mencakup pembahasan fikih pada berbagai macam
aspek.Materi yang diambil dari buku ini adalah spesifik tema hadis, baik yang klasik maupun kontemporer.

2. Fiqh Az-Zakah

Buku ini adalah masterpiece Yusuf Qardawi yang merupakan referensi mayoritas orang untuk tema zakat.Dikarenakan buku ini membahas secara komprehensif seluruh tema zakat, maka yang difokuskan hanyalah pada zakat pertanian.

3. Al-Mausuah Al-Fiqhiyyah Al-Kuwaitiyyah

Buku ini adalah salah satu ensiklopedi Islam yang paling komprehensif membahas seluruh aspek fikih dari pandangan seluruh empat mazhab hingga pendapat para Sahabat. Tema yang akan diambil dikhususkan pada materi zakat pertanian.

4. Zakat dalam Perkonomian Modern

Tema yang akan disadur dari buku ini adalah terkait lembaga dan organisasi pengelola zakat.

5. Fiqh dan Manajemen Zakat di Indonesia

Buku yang disusun berdasarkan kerini dijadikan referensi untuk secara khusus membahas zakat dalam konteks Indonesia.

Pada penyuluhan dalam rangka pengabdian masyarakat ini setidaknya ada 18 poin materi yang terbagi menjadi 3 hal pokok. Yang pertama adalah tentang pengetahuan awal dan dasar.Kategori materi yang kedua adalah teknis zakat pertanian dengan spesifik padi.Setelah kedua materi tersebut, maka dilanjutkan dengan tentang manajemen zakat oleh instansi zakat di Indonesia sebagai kelompok materi ketiga. Tentunya bobot semua materi ini akan disesuaikan dengan kemampuan audiens. Adapun judul kelompok poin materi secara rinci adalah sebagai berikut:

1. Poin pertama: Bahwa zakat fitri dan zakat harta itu berbeda

2. Poin kedua: Bahwa zakat harta itu ada bermacam-macam jenisnya

3. Poin ketiga: Bahwa hasil panen pertanian itu wajib dibayarkan zakatnya

4. Poin keempat: Tentang nisob

5. Poin kelima: Tentang haul 
6. Poin keenam: Bahwa zakat pertanian dibayarkan setiap kali panen

7. Poin ketujuh: Bahwa kadar zakat padi yang dibayarkan berbeda tergantung jenis pengairan

8. Poin kedelapan: Bahwa zakat pertanian itu wajib hanya jika mencapai 653 kilogram

9. Poin kesembilan: bahwa kadar zakat padi dihitung berdasar bulir beras, bukan gabah

10. Poin kesepuluh: bahwa zakat pertanian hanya diwajibkan kepada pemilik lahan

11. Poin kesebelas: bahwa zakat pertanian yang wajib dibayarkan tidak dikurangi biaya operasional

12. Poin keduabelas: bahwa zakat pertanian tidak boleh diganti pembayarannya dengan uang menurut sebagian ulama

13. Poin ketigabelas: bahwa petani yang telah membayarkan zakat pertaniannya tidak perlu membayar zakat barang niaga jika ia menjual hasil pertanian tersebut

14. Poin keempatbelas: tentang BAZNAS

15. Poin kelimabelas: tentang LAZIS

16. Poin keenambelas: bahwa membayar zakat bisa melalu perantara

17. Poin ketujuhbelas: bahwa distribusi zakat di Indonesia kurang merata

18. Poin kedelapanbelas: bahwa pemerintah telah berusaha meratakan distribusi zakat
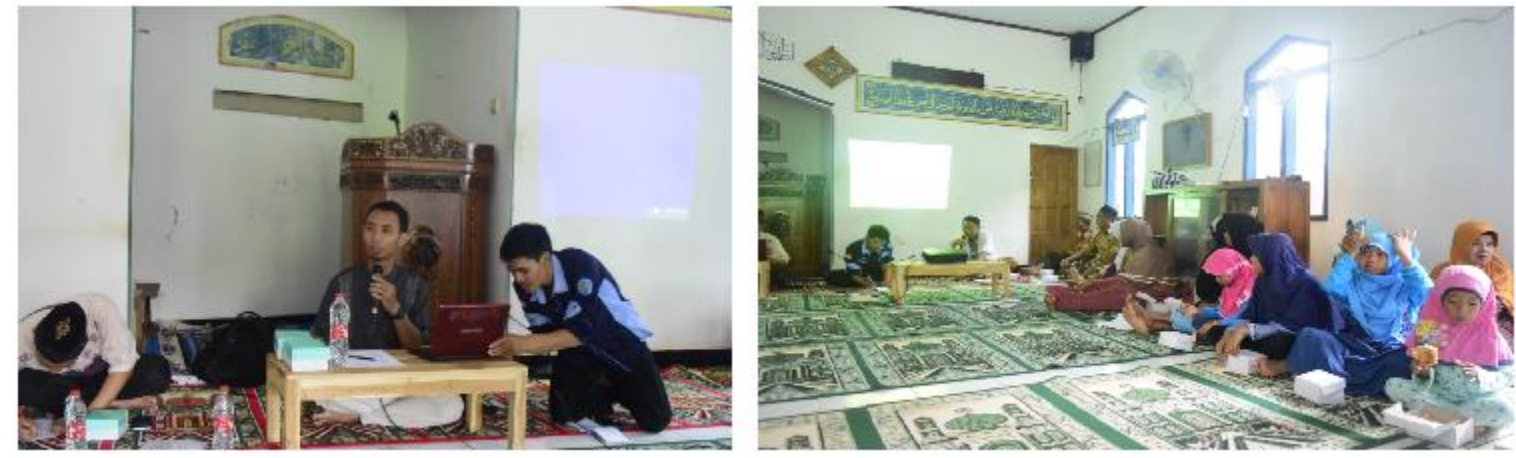

Gambar 1. Pemateri menyampaikan materi penyuluhan zakat

Seluruh poin-poin di atas akan disampaikan dengan kadar pendalaman sesuai dengan kebutuhan masyarakat sekitar. Maka dari itu, tidak akan ada argumentasi perbedaan pendapat antar ulama yang diejawantahkan pada proses penyuluhan. Poin-poin yang cukup dibahas singkat juga akan disampaikan dengan ringkas langsung kepada titik permasalahan.

\section{HASIL PELAKSANAAN KEGIATAN}

Pelaksanaan kegiatan pengabdian ini mendapatkan serta menyajikan 2 hal penting. Yang pertama adalah terkait materi yang bisa tersampaikan kepada peserta. Kedua adalah dialog interaktif dengan peserta. Ketiga adalah hasil pendataan akan tingkat pemahaman peserta.

\section{Materi yang tersampaikan}

Dalam penyuluhan ini disampaikan 18 poin terkait teori dan praktek zakat padi dengan tiga kategori utama. Kategori pertama adalah pengetahuan umum terkait zakat, kategori kedua adalah teknis zakat padi, sedangkan kategori ketiga adalah instansi pengurus zakat. Adapun ringkasan materi yang disampaikan adalah sebagai berikut:

a) Poin pertama: Bahwa zakat fitri dan zakat harta itu berbeda.

Poin ini sengaja disampaikan untuk meluruskan ulang pemahaman masyarakat bahwa zakat fitri itu berbeda dengan zakat harta. Untuk simplifikasi materi, maka hanya disampaikan bahwa zakat fitri itu dibayar setahun sekali ketika bulan ramadan, sedangkan zakat harta itu tidak pasti setahun sekali. 


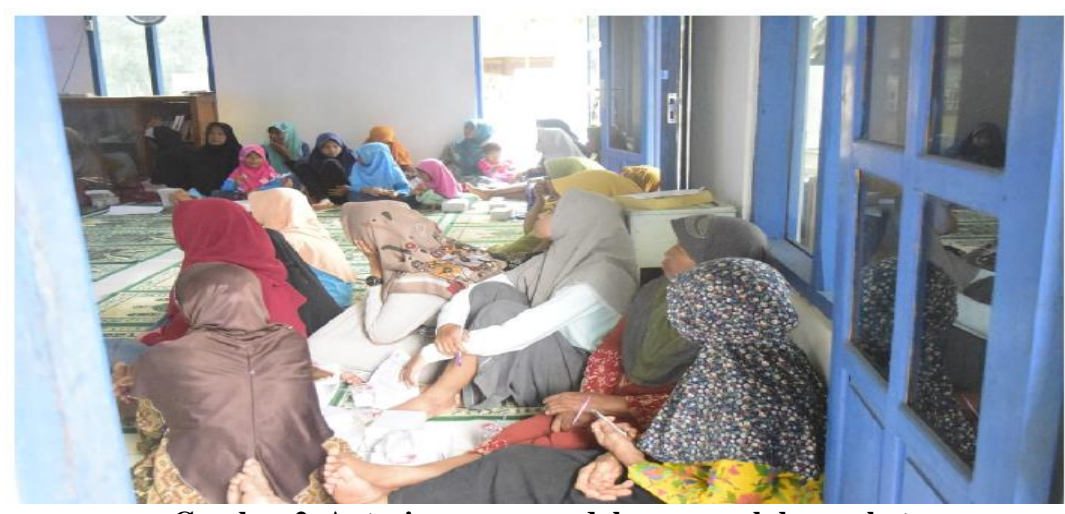

Gambar 2. Antusiasme warga dalam penyuluhan zakat

b) Poin kedua: Bahwa zakat harta itu ada bermacam-macam jenisnya

Poin ini disampaikan untuk sekaligus memperkaya perbedaan dengan zakat fitri pada poin pertama. Poin ini juga disampaikan dengan sangat sederhana, dengan menyebutkan bahwa ada 5 setidaknya zakat yang disepakati oleh para ulama. Kelima zakat itu adalah zakat barang dagang, zakat uang (naqdain), zakat tambang, zakat ternak serta zakat pertanian.

c) Poin ketiga: Bahwa hasil panen pertanian itu wajib dibayarkan zakatnya

Poin ini merupakan elaborasi dari poin sebelumnya, spesifik pada zakat pertanian. Materi yang disampaikan adalah bahwasanya ada beberapa hasil pertanian yang wajib dizakati, sedangkan sebagian yang lain tidak.

d) Poin keempat: Tentang nisob

Nisob merupakan salah satu materi paling dasar dalam zakat, sehingga materi ini masuk dalam kategori pengetahuan dasar. Poin yang disampaikan bahwa nisob adalah kadar berat yang merupakan batasan antara wajib dan tidak wajib zakat. Materi dibuat sederhana dengan menyatakan bahwa sebelum sampai nisob, maka tidak wajib zakat, sedangkan jika sudah mencapai, maka wajib membayar zakat.

e) Poin kelima: Tentang haul

Haul juga materi yang sangat mendasar dalam masalah zakat. Materi ini disampaikan dengan ringkas. Jika nisob adalah syarat kadar kuantitas, maka haul adalah syarat kadar waktu. Maka beberapa zakat baru diwajibkan jika telah penuh kadar waktunya, yaitu satu tahun hijriah. f) Poin keenam: Bahwa zakat pertanian dibayarkan setiap kali panen

Setelah menyampaikan pemahaman dasar zakat, selanjutnya penyuluhan diarahkan kepada hal teknis. Pertama dimulai dari penekanan bahwa meskipun kita mengenal istilah haul, tetapi hal ini tidak berlaku untuk zakat pertanian, termasuk zakat padi. Untuk itu diharap agar warga bisa lebih jeli dalam memahami permasalahan.

g) Poin ketujuh: Bahwa kadar zakat padi yang dibayarkan berbeda tergantung jenis pengairan

Kalaupun zakat padi harus dibayarkan langsung setelah panen, maka ada keterangan tambahan yaitu besaran padi yang dizakatkan berbeda antara diberi air sendiri atau dari air hujan. Jenis pertama membuat zakat wajib sebanyak $5 \%$, sedangkan yang kedua $10 \%$.

h) Poin kedelapan: Bahwa zakat padi itu wajib hanya jika mencapai 653 kilogram

Meskipun tidak ada haul, zakat padi itu wajib hanya jika mencapai 653 kilogram. Di sini ditekankan kepada warga bahwa jika memang kadar panen tidak mencapai berat tersebut, maka warga tidak termasuk dalam golongan wajib zakat.

i) Poin kesembilan: bahwa kadar zakat padi dihitung berdasar bulir beras, bukan gabah

Miskonsepsi atau kesalahpahaman yang biasa terjadi di masyarakat awam selain terkait nisob padi yang 653 kilogram adalah definisi dari angka 653 kilogram itu sendiri. Pada penyuluhan ini ditekankan bahwa yang dimaksud dengan angka nisob tersebut dihitung dari bulir beras, bukan 
gabahnya. Jika seseorang panen 1050 kilogram, tetapi setelah diayak gabahnya menjadi bulir beras berkurang menjadi $640 \mathrm{~kg}$, maka tidak wajib baginya membayar zakat.

j) Poin kesepuluh: bahwa zakat pertanian hanya diwajibkan kepada pemilik lahan

Kesalahpahaman lain yang bisa kita temukan adalah kewajiban zakat yang sebenarnya hanya dibebankan kepada pemilik. Maka, buruh tani tentunya tidak diwajibkan zakat. Memang dalam banyak kasus buruh tani mendapat bayaran berupa padi itu sendiri. Maka dari itu, ditekankan dalam penyuluhan ini bahwa meskipun upah yang diterima sampai kepada $653 \mathrm{~kg}$ bulir beras, tetapi tidak wajib baginya zakat pertanian.

k) Poin kesebelas: bahwa zakat pertanian yang wajib dibayarkan tidak dikurangi biaya operasional

Dalam bercocok tanam tentu memerlukan modal yang besar. Dalam hal ini, banyak ulama mengatakan bahwa kadar zakat tidak dikurangi biaya operasional. Sebaian ulama kontemporer mengatakan dikurangi biaya operasional.

1) Poin keduabelas: bahwa zakat pertanian tidak boleh diganti pembayarannya dengan uang menurut sebagian ulama

Bagi sebagian ulama, zakat padi harus dibayar padi, zakat kurma harus dibayar kurma, dan seterusnya. Meskipun begitu, sebagian ulama kontemporer menyatakan boleh membayar zakat pertanian berupa uang dengan harga setara.

m) Poin ketigabelas: bahwa petani yang telah membayarkan zakat pertaniannya tidak perlu membayar zakat barang niaga jika ia menjual hasil pertanian tersebut

Kesalahpahaman lain yang sering terjadi adalah bahwa setelah membayar zakat padi, mereka masih membayar zakat barang niaga dikarena hasil panen itu mereka perdagangkan. Hal ini tidak benar karena kewajiban zakatnya dalam hal komoditas tersebut sudah selesai.

n) Poin keempatbelas: tentang BAZNAS
Jika sudah panen dan siap membayar zakat, maka pemerintah memberi fasilitas kepada rakyat, yaitu BAZNAS. Badan ini membantu pengumpulan serta distribusi zakat.

o) Poin kelimabelas: tentang LAZIS

Seringkali badan yang dibentuk pemerintah tersebut tidak bisa mencapai ke seluruh pelosok desa. Maka dari itu, banyak inisiatif swasta untuk membantu pemerintah. Badan dengan fungsi seperti BAZNAS yang dibentuk swasta disebut LAZIS.

p) Poin keenambelas: bahwa membayar zakat bisa melalui perantara

Poin ini ingin menekankan bahwa karena tidak semua orang paham kepada siapa membayar zakat, maka boleh melalui perantara yaitu LAZIS dan BAZNAS tersebut.

q) Poin ketujuhbelas: bahwa distribusi zakat di Indonesia kurang merata

Indonesia mempunyai masalah dalam hal distribusi zakat. Ada golongan yang menerima dua kali atau lebih, di sisi lain ada yang belum mendapat sama sekali. Pembayaran zakat melalui perantara justru membantu pemerataaan penyaluran zakat.

r) Poin kedelapanbelas: bahwa pemerintah telah berusaha meratakan distribusi zakat

Mengahadapi masalah ketidakrataan itu, pemerintah telah melakukan banyak usaha seperi sosialisasi. Akan tetapi terlalu banyak desa yang jauh dari jangkauan sehingga dibutuhkan sosialisasi non formal dari penyuluh seperti yang sedang dilakukan dalam program ini.

\section{Dialog Interaktif dengan Peserta}

Penyuluhan tentang zakat ini dibarengi dengan dialog interaktif bersama warga yang sengaja dibangun agar ada timbal balik dari peserta. Selain itu, dialog interaktif diadakan agar tidak menjadi pembicaraan searah tanpa mengetahui masalah asli yang terjadi di lapangan. Dengan adanya dialog interaktif maka juga akan terbentuk pendalaman materi yang telah disampaikan dengan menggunakan kasus lapangan dari yang dialami warga Bendosari Rt.02/Rw.01 


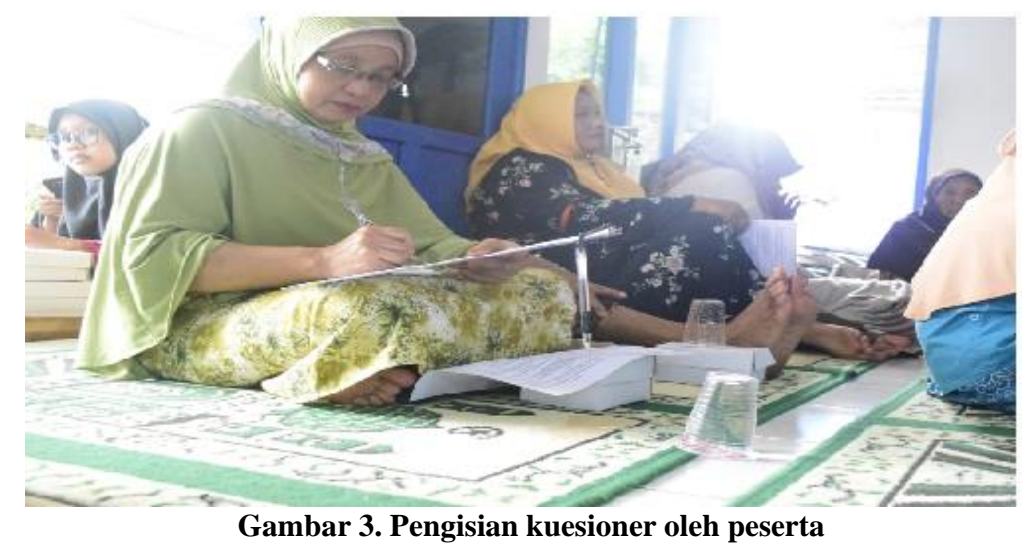

Pertanyaan pertama yang diajukan oleh peserta adalah terkait realita masyarakat dan kondisi desa Bendosari Rt.02/Rw.01 bahwa banyak yang memiliki lahan pertanian baik itu sawah maupun ladang tetapi kecil. Warga pun bertanya apakah zakat masih diwajibkan bagi mereka yang mempunyai ladang kecil. Tentunya jawaban ini sebetulnya sudah disampaikan pada materi penyuluhan dengan gamblang. Pertanyaan ulang dari jamaah semakin membantu peserta untuk memahami materi dengan kasus mereka sendiri.

Wajib tidaknya zakat tentunya tidak dipatok dengan luas ladang yang dimiliki, melainkan melalui haul dan nisob. Dalam hal pertanian, maka yang dijadikan patokan adalah nisob saja. Jika luas ladang dijadikan patokan, maka ketentuan zakat menjadi rancu karena pada era sekarang ini sudah ada kemajuan teknologi dalam bercocok tanam. Dengan teknologi tersebut sebuah tanaman bisa ditumbuhkan pada ruangan tertutup dengan luas yang jauh lebih kecil dari pada ladang secara umum, tetapi menghasilkan buah yang jauh lebih banyak. Ketentuan Islam yang membuat patokan zakat berdasarkan kuantitas ini juga menunjukkan kehebatan Islam karena membuatnya relevan untuk segala zaman.

Maka dari itu, baik kepada penanya maupun warga secara kesuluruhan harus memperhatikan hasil panen yang didapat dari ladang tersebut. Jika hasil panennya termasuk dalam kategori yang wajib zakat, maka itu menjadi parameter pertama. Patokan selanjutnya tentunya nisob, jika memenuhi kadar wajib zakat, maka ia harus mengeluarkan zakatnya terlepas dari ukuran ladang yang ia miliki.
Pertanyaan selanjutnya juga masih berasal dari kondisi warga desa Bendosari Rt.02/Rw.01 yaitu terkait penyaluran zakat. Lokasi desa ini yang lumayan jauh dari perkotaan maupun akses menuju kota membuat keberadaan BAZNAS ataupun LAZIS menjadi sulit didapati. Untuk mengatasi hal tersebut, sebagian warga menyalurkannya melalui takmir masjid. Takmir sendiri kemudian membagikan kembali tetapi kepada warga desa, bukan kepada BAZNAS. Warga masih ragu apakah praktek mereka selama ini benar atau tidak.

Sama dengan penanya sebelumnya, pertanyaan ini juga sebetulnya sudah disinggung dalam materi penyuluhan terkait tentang BAZNAS, pembayaran serta distribusi zakat. Pertanyaan kali ini juga mampu membantu memberi pendalaman peserta lain terkait praktek manajemen zakat.

Pada hakekatnya zakat bisa diberikan secara langsung kepada 8 golongan yang berhak menerimanya sebagaimana disebut dalam Alquran. Akan tetapi, tidak semua orang bisa mengidentifikasi 8 golongan tersebut dalam kehidupan nyata sehingga justru membebani pembayar jika diharuskan untuk mendistribusikan secara langsung. Kehadiran BAZNAS adalah untuk membantu pengumpulan zakat sekaligus pendistribusiannya.

Berdasarkan fungsi tersebut, maka jika takmir masjid bisa menjalankan hal yang sama maka sudah sangat membantu tugas BAZNAS terlepas bahwa distribusi yang dilakukan takmir masjid masih saja berkutat pada warga sekitar. Meskipun tentu akan lebih baik jika pihak takmir bisa melakukan koordinasi dengan BAZNAS 
terkait distribusi zakat ini agar pendistribusian menjadi jauh lebih optimal.

\section{Hasil Survey Kuesioner}

Untuk memastikan pemahaman peserta, maka penyuluhan ini membuat kusioner terkait materi yang akan disampaikan. Kuesioner disusun menjadi dua kategori, yaitu pra dan pasca penyuluhan. Kuesioner pra penyuluhan diadakan untuk mengukur pemahaman peserta sebelum mendapat materi. Model pertanyaan adalah tertutup dengan diksi dan pilihan jawaban yang disesuaikan dengan karakter masyarakat. Premis pertanyaan adalah "apakah anda tahu" sehingga benar-benar mengukur pemahaman peserta. Adapun hasil dari kuesioner pra penyuluhan adalah sebagai berikut:

Tabel 5.1. Pemahaman Peserta Pra Penyuluhan

\begin{tabular}{llcccc}
\hline \multicolumn{2}{c}{ Umum } & & & \\
\hline No & \multicolumn{1}{c}{ Pertanyaan } & Ya & Tidak & $\begin{array}{c}\text { Pernah } \\
\text { Tahu }\end{array}$ \\
\hline 1 & Perbedaan zakat fitri dan harta & 12 & 1 & 5 \\
\hline 2 & Macam jenis zakat harta & 15 & 0 & 3 \\
\hline 3 & Wajibnya zakat dari hasil panen pertanian & 10 & 5 & 3 \\
\hline 4 & Pengertian Nisob & 9 & 6 & 3 \\
\hline 5 & Pengertian Haul & Total & 7 & 9 & 2 \\
\hline & & 53 & 21 & 16 \\
\hline
\end{tabular}

\begin{tabular}{clccc}
\hline \multicolumn{1}{c}{ Teknis } & \multicolumn{1}{c}{ Pertanyaan } & Ya & Tidak & $\begin{array}{c}\text { Pernah } \\
\text { Tahu }\end{array}$ \\
\hline No & \multicolumn{1}{c}{$\begin{array}{c}\text { Zakat pertanian dibayar setiap kali panen } \\
1\end{array}$} & 5 & 1 \\
\hline 2 & $\begin{array}{l}\text { kadar zakat padi dibayarkan berbeda tergantung jenis } \\
\text { pengairan }\end{array}$ & 5 & 5 \\
\hline 3 & Zakat pertanian wajib jika mencapai 653 kg & 3 & 10 & 5 \\
\hline 4 & $\begin{array}{l}\text { Kadar zakat pertanian hitungan untuk bulir beras bukan } \\
\text { gabah }\end{array}$ & 5 & 10 & 2 \\
\hline 5 & $\begin{array}{l}\text { Zakat pertanian hanya diwajibkan kepada pemilik lahan } \\
\text { Zakat pertanian yang wajib dibayarkan tidak dikurangi } \\
\text { biaya operasional }\end{array}$ & 7 & 11 & 0 \\
\hline 7 & $\begin{array}{l}\text { Zakat pertanian tidak boleh diganti pembayarannya dengan } \\
\text { uang menurut sebagian ulama }\end{array}$ & 4 & 9 & 5 \\
\hline 8 & $\begin{array}{l}\text { Petani membayar zakat pertanian tidak perlu membayar } \\
\text { zakat barang niaga jika ia menjual hasil pertanian }\end{array}$ & 4 & 11 & 3 \\
\hline & Total & 40 & 78 & 25 \\
\hline & & & \\
\hline
\end{tabular}

\begin{tabular}{llcccc}
\hline \multicolumn{2}{c}{ Manajemen } & & & \\
\hline No & & Pertanyaan & Ya & Tidak & $\begin{array}{c}\text { Pernah } \\
\text { Tahu }\end{array}$ \\
\hline 1 & Mengenal BAZNAS & 9 & 6 & 3 \\
\hline 2 & Mengenal LAZIS & 5 & 10 & 3 \\
\hline 3 & Pembayaran zakat bisa melalui perantara & 7 & 6 & 5 \\
\hline 4 & Distribusi zakat di Indonesia kurang merata & 5 & 10 & 3 \\
\hline 5 & $\begin{array}{l}\text { Usaha yang dilakukan pemerintah agar distribusi zakat } \\
\text { merata }\end{array}$ & 2 & 11 & 5 \\
\hline & Total & 28 & 43 & 19 \\
\hline
\end{tabular}

Dari kuesioner di atas bisa dilihat bahwa teknis serta manajemen mayoritas warga belum untuk pemahaman umum memang mayoritas paham tentang hal tersebut. sudah paham. Akan tetapi, jika masuk kepada hal

Untuk membandingkan dengan hasil pasca penyuluhan, maka diadakan kusioner juga. 
Pertanyaan kuesioner adalah pilihan ganda berdasarkan materi yang disampaikan ketika penyuluhan. Rekapitulasi yang disajikan pada tabel di bawah menunjukkan jumlah pertanyaan yang dijawab dengan benar, salah ataupun tidak tahu. Adapun hasil dari kuesioner tersebut sebagai berikut:

Tabel 5.2. Pemahaman Peserta Pasca Penyuluhan

\begin{tabular}{|c|c|c|c|c|}
\hline \multicolumn{5}{|c|}{ Umum } \\
\hline No & Pertanyaan & Benar & Salah & $\begin{array}{l}\text { Tidak } \\
\text { Tahu }\end{array}$ \\
\hline 1 & Perbedaan zakat fitri dan harta & 20 & 1 & 2 \\
\hline 2 & Macam jenis zakat harta & 20 & 2 & 1 \\
\hline 3 & wajibnya zakat dari hasil panen pertanian & 20 & 2 & 1 \\
\hline 4 & Pengertian Nisob & 19 & 1 & 3 \\
\hline 5 & Pengertian Haul & 7 & 13 & 3 \\
\hline & Total & 86 & 19 & 10 \\
\hline \multicolumn{5}{|c|}{ Teknis } \\
\hline No & Pertanyaan & Benar & Salah & $\begin{array}{l}\text { Tidak } \\
\text { Tahu } \\
\end{array}$ \\
\hline 1 & Zakat pertanian dibayar setiap kali panen & 18 & 2 & 3 \\
\hline 2 & $\begin{array}{l}\text { kadar zakat padi dibayarkan berbeda tergantung jenis } \\
\text { pengairan }\end{array}$ & 12 & 8 & 3 \\
\hline 3 & Zakat pertanian wajib jika mencapai $653 \mathrm{~kg}$ & 16 & 2 & 5 \\
\hline 4 & $\begin{array}{l}\text { Kadar zakat pertanian hitungan untuk bulir beras bukan } \\
\text { gabah }\end{array}$ & 14 & 6 & 3 \\
\hline 5 & Zakat pertanian hanya diwajibkan kepada pemilik lahan & 17 & 4 & 2 \\
\hline 6 & $\begin{array}{l}\text { Zakat pertanian yang wajib dibayarkan tidak dikurangi } \\
\text { biaya operasional }\end{array}$ & 18 & 0 & 5 \\
\hline 7 & $\begin{array}{l}\text { Zakat pertanian tidak boleh diganti pembayarannya dengan } \\
\text { uang menurut sebagian ulama }\end{array}$ & 18 & 2 & 3 \\
\hline 8 & $\begin{array}{l}\text { Petani membayar zakat pertanian tidak perlu membayar } \\
\text { zakat barang niaga jika ia menjual hasil pertanian }\end{array}$ & 11 & 6 & 6 \\
\hline & Total & 124 & 30 & 30 \\
\hline \multicolumn{5}{|c|}{ Manajemen } \\
\hline No & Pertanyaan & Benar & Salah & $\begin{array}{l}\text { Tidak } \\
\text { Tahu }\end{array}$ \\
\hline 1 & Mengenal BAZNAS & 11 & 8 & 4 \\
\hline 2 & Mengenal LAZIS & 13 & 7 & 3 \\
\hline 3 & Pembayaran zakat bisa melalui perantara & 20 & 3 & 0 \\
\hline 4 & Distribusi zakat di Indonesia kurang merata & 15 & 5 & 3 \\
\hline 5 & $\begin{array}{l}\text { Usaha yang dilakukan pemerintah agar distribusi zakat } \\
\text { merata }\end{array}$ & 17 & 4 & 2 \\
\hline & Total & 76 & 27 & 12 \\
\hline
\end{tabular}

Kuesioner pasca penyuluhan di atas menunjukkan peningkatan yang signifikan pada pemahaman peserta. Peningkatan itu terdapat pada seluruh kategori, yaitu pemahaman umum, teknis zakat serta manajemen. Meskipun masih ada pertanyaan yang dijawab dengan salah, hal itu minor dibandingkan jumlah responden yang menjawab dengan benar.

\section{KESIMPULAN DAN SARAN}

Kegiatan pengabdian masyarakat seperti ini memang sangat dinanti warga yang menempati daerah sulit terjangkau oleh para dai dan penyuluh agama. Termasuk juga pengabdian masyarakat dengan topik zakat padi yang telah dilaksanakan di desa Al-Ikhlas ini dapat menarik animo warga desa Bendosari Rt.02/Rw.01 
Sukoharjo sebagaimana dilihat dari jumlah kehadiran pada saat penyuluhan.

Urgensi penyuluhan seperti ini sendiri bisa dilihat dari 2 hal. Pertama, dilihat dari dialog interaktif, banyak pemahaman warga yang memang kurang tepat terkait praktik zakat. Jika masyarakat dibiarkan linglung dalam pemahaman yang kurang tepat, tentunya berakibat besar pada praktek zakat dalam kehidupan mereka. Tidak adanya penyuluhan terkait topik ini tentu menjadi salah satu pemicunya. Kedua, dilihat dari kuesioner bahwa pemahaman warga meningkat signifikan setelah adanya penyuluhan menunjukan pada hakikatnya masyarakat dapat memahami topik zakat. Yang mereka perlukan adalah adanya penyuluhan berkesinambungan untuk terus meningkatkan pemahaman masyarakat.

Dari hasil pengabdian masyarakat ini, dapat disarankan bahwa perlu diadakan kegiatan penyuluhan terus menerus bagi warga guna meningkatkan pemahaman mereka. Penyuluhan juga agar tidak tebang pilih hanya kepada masyarakat yang mudah dijangkau tempatnya, tetapi juga masyarakat pelosok karena terbukti mereka juga butuh serta mampu mencerna materi yang diberikan.

\section{DAFTAR PUSTAKA}

Mubarok, A., \& Fanani, B. (2014). Penghimpunan dana zakat nasional (Potensi, realisasi dan peran penting organisasi pengelola zakat). Permana, 5(2).

Canggih, C., Fikriyah, K., \& Yasin, A. (2017).Potensi Dan Realisasi Dana Zakat Indonesia. Al-Uqud: Journal of Islamic Economics, 1(1), 14-26.

Mukhlis, A., \& Beik, I. S. (2013). Analisis Faktor-faktor yang Memengaruhi Tingkat Kepatuhan Membayar Zakat: Studi Kasus Kabupaten Bogor. Al-Muzara'ah, 1(1), 83106.

Kurniawati. (2004). Kedermawanan kaum Muslimin : potensi dan realita zakat masyarakat di Indonesia. Jakarta: Piramedia (PIRAC)

Sitorus, R. (2015). Baznas Targetkan Dana Zakat 2015 sebesar Rp. 4.8 Triliun. Diakses dari http://industri.bisnis.com/read/20150630/1 2/448787/baznas-targetkan-dana-zakat2015-sebesar-rp48-triliun.html.

Sedjati, D. P., Basri, Y. Z., Hasanah U. (2018). Analysis of Factors Affecting the Payment of Zakat in Special Capital Region (DKI) of Jakarta. International Journal of Islamic Busienss and Management. (2) 1: 24-34.

Huda, N., Rini N., Mardoni, Y., Putra, P. (2012). The Analysis of Attitude, Subjective Norms and Behavioral Control on Muzakki's Intention to Pay Zakah. International Journal of Business and Social Science. (3), 22: 271-279 